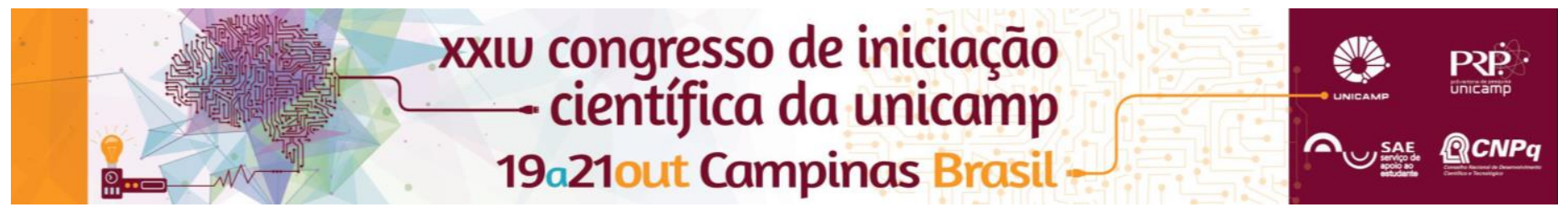

\title{
Capiroto, o homem, o bicho - Estudo a partir do Eixo Estruturação da Personagem no Método BPI
}

\author{
Igor M. R. Costa* (IC), Larissa Sato Turtelli (Orientadora).
}

\section{Resumo}

Este projeto previu uma pesquisa em dança, como continuidade do projeto de Iniciação Cientifica anterior " O Corpo no corte da cana - Pesquisa de Campo a partir do Co-habitar com a Fonte no Método BPI", sob o enfoque do Método Bailarino-Pesquisador-Intérprete (BPI). A pesquisa teve como foco o eixo Estruturação da Personagem do Método $\mathrm{BPI}$, tendo assim como objetivo empreender um processo criativo e estruturar uma personagem neste método. A base para esta pesquisa foram as pesquisas de campo feita com os cortadores de cana e as comunidades terreiro da cidade de Cachoeira-BA. Chegou-se com esta pesquisa à criação de um espetáculo, juntamente à mais quatro bailarinas-pesquisadoras-interpretes, também com projetos de iniciação científica.

\section{Palavras-chave}

Dança, Método BPI, Estruturação da Personagem.

\section{Introdução}

A presente pesquisa deu-se como continuidade da primeira iniciação científica na qual houvera uma pesquisa de campo com cortadores de cana de Ibirarema(SP) e, mais profundamente, com comunidades terreiro de Cachoeira-BA no ano de 2015. Pretendeu-se com a atual pesquisa uma investigação dentro do terceiro eixo do Método Bailarino-Pesquisados-Intérprete (BPI), a Estruturação da Personagem, chegando a uma elaboração artística a partir, das pesquisas de campo realizadas e de todo o desenvolvimento técnico e expressivo, iniciado nas disciplinas de Dança do Brasil no curso de Graduação em Dança da Unicamp e desenvolvido nas duas iniciações científicas. Estabeleceu-se uma relação desta pesquisa com as de outras quatro pesquisadoras com iniciação científica no Método $\mathrm{BPI}$ as quais partilharam a mesma pesquisa de campo em Cachoeira-BA, resultando em um espetáculo de Dança que congregou as cinco investigações.

\section{Resultados e Discussão}

A partir dos estudos de campo, e posterior a este, houveram-se laboratórios dirigidos, momento o qual juntamente à orientadora, há o reconhecimento da memória e dos percursos internos do Inventário no Corpo e do que ressoou do contato com o campo de pesquisa (Rodrigues, 2013). Sendo levantado através do movimento e sua leitura, e análise, dos dados descritos em diários que foram registrados por parte do pesquisador a fim de elaborar o conteúdo que eram dia a dia evidenciados pelo corpo. Chegou-se assim a nucleação de conteúdos (movimentos, emoções, sensações, imagens) que delinearam a personagem chamada Essaia, ligada ao arquétipo de Exu. Fora também colocado neste momento de pesquisa além do desenvolvimento individual ao decorrer do desenvolvimento da personagem foi-se relacionado os conteúdos à mais outras quatro pesquisadoras e suas respectivas personagens, advindas da mesma pesquisa de campo, onde chegou-se a uma síntese cênica.
Figura 1. Essaia à esq. e a personagem Bela à dir. no espetáculo "Depois daquele canto - 2015" foto: Wers Gravaluz

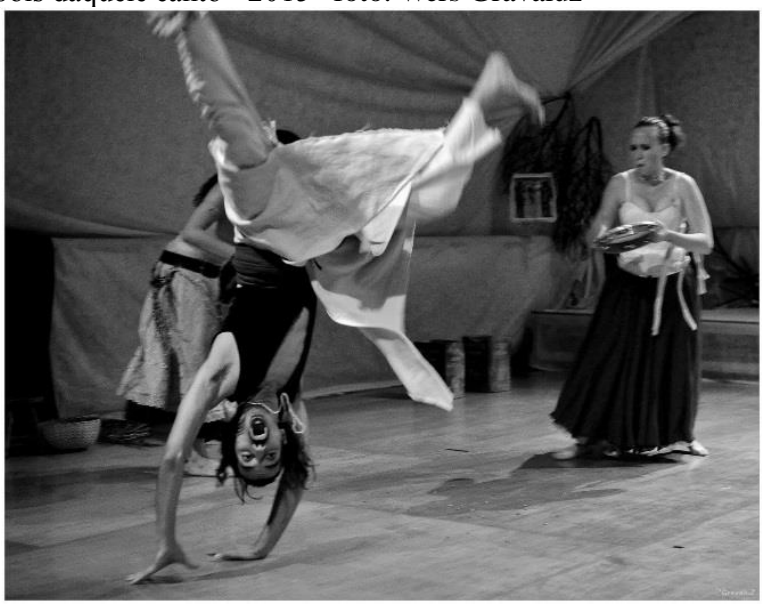

\section{Conclusões}

É visto que houve o desenvolvimento pessoal do pesquisador quanto artista-pesquisador, ao desenvolver as inquietações emergentes durante a graduação nas duas iniciações científicas. Tendo este percurso possibilitado um melhor entendimento à cerca do Método BPI e principalmente das possibilidade do fazer artístico Foi possível com o desenvolvimento e Estruturação da Personagem vivenciar no corpo significâncias a respeito da singularidade (alteridade) a qual este tipo de pesquisa permitiu ao bailarino-pesquisador-intérprete, desenvolvimento de sua linguagem corporal, e a elaboração de conteúdos simbólicos internos que no lugar de encontro com o Outro do campo transliterou-se como obra artística.

\section{Agradecimentos}

Ao povo de santo de Cachoeira-BA, aos cortadores de cana. À Larissa Turtelli, Graziela Rodrigues e Elisa Costa. Ao Programa de Iniciação Cientifica (CNPQ) e ao Departamento de Artes Corporais.

RODRIGUES, Graziela Estela Fonseca. "O Método BPI (BailarinoPesquisador-Intérprete) e o desenvolvimento da imagem corporal: reflexões que consideram o discurso de bailarinas que vivenciaram um processo criativo baseado neste método. " Campinas, 2003. 171p. Tese de Doutorado. 